\title{
Factors Affecting Hospital Service Innovation; Literature Review
}

\author{
Siti Fatmala Rezeki ${ }^{1}$, Syahrir A. Pasinringi ${ }^{1}$, Lalu Muhammad Saleh ${ }^{2}$ \\ ${ }^{1}$ Hospital Management Department, Faculty of Public Health, Hasanuddin University, Indonesia \\ ${ }^{2}$ Department of Occupational Health and Safety, Faculty of Public Health, Hasanuddin \\ University, Indonesia
}

Received: October 26, 2020

Revised: November 5, 2020

Accepted: November 8, 2020

\begin{abstract}
Innovation at the hospital as a change in the delivery of patient-focused health services by encouraging healthcare professionals to work smarter, faster and better. Service innovation can provide an effective way to create a sustainable competitive advantage for hospitals. This study aims to analyze and examine the factors that influence service innovation in hospitals using the literature review method. The results were obtained from a literature search that discusses the major factors that influence service innovation, namely in the form of a good management system within the scope of the hospital. This big influence is that human resources, starting from the leaders and employees who work in the hospital, must work together for the advancement and empowerment of the hospital.
\end{abstract}

Keywords: Influence Factors, Service Innovation, Hospital

\section{Introduction}

Hospital is a health service institution that plays a role in providing complete individual health services. The role of the hospital, which is quite comprehensive, describes an organization that is very complex, capital intensive, technology intensive, labor intensive, professional and system intensive. In addition, the uniqueness of hospital services is influenced by the values held by patients. The Institute of Medicine (IOM) explained that the quality of health service institutions is aimed at providing safe, effective, patient-centered, timely, efficient, and equitable services, one of which is Patient Centered Care (PCC).

The PCC concept is an innovative approach to health care planning, service and evaluation based on mutually beneficial partnerships between health care providers, patients and families. PCC as a care-friendly and responsive to individual patient choices, needs, and values, and ensures patients make clinical decisions (Medicine, 2001). This concept is to provide services to patients by referring and respecting individuals including preferences / choices, needs, values, which aims to create patient satisfaction, improve the quality of clinical results, reduce excessive and useless medical services, reduce the possibility of malpractice and complaints, and reduce health costs.

In facing free market competition, hospitals must be able to survive and need to formulate appropriate marketing strategies, by carrying out various innovations according to community needs. With the change in the paradigm of hospitals entering free market competition, regulatory developments, people's need for health services is increasing, responding to millennial society, technological developments in the health sector, so hospitals need to make innovations. 
Innovation in the hospital is defined as a change in the delivery of patient-focused healthcare by encouraging healthcare professionals to work smarter, faster and better. Pervaiz K. Ahmed and Charles D. Shepherd (2010) argued that organizational innovation can produce R\&D (Research and Development), production and marketing approaches. Innovation is creating or adopting new ideas, products, services, programs, technology, policies, structures or new administrative systems.

Service innovation is to provide new services to customers. In line with this definition, service innovation is creating a new service or significantly improving an existing service. Service innovation can provide an effective way to create a sustainable competitive advantage for a company.

Innovation is a widely studied field. This is critical for any organization looking to achieve and maintain a competitive advantage in the marketplace, although assessing the impact of innovation is a challenge due to the difficulty of isolating and measuring it. In addition, health institutions in the face of improvement need innovation in order to compete and offer new treatments to patients. Curiously, little is known about innovation in health care organizations and their relationship to performance.

Service innovation "has become a term that refers to innovation that occurs in a variety of service contexts, including the introduction of new services or the incremental improvement of existing services. In recent decades, healthcare innovation has increased with product, care and care delivery technologies. improve patient life expectancy and quality of life, and make access to services and pathways of care easier Innovations in health care result in efficiencies, reduced costs and human error.

However, making service innovations is not an easy thing so that in the process there are several things that can influence a service innovation to succeed or not, especially in the health sector in hospitals. For this reason, the authors are interested in examining some of the literature regarding what factors can influence service innovation in hospitals.

\section{Methods}

This study uses a narrative literature review model which aims to review and study several literature on the same topic. Determining the title in the literature review, namely the factors that influence service innovation in hospitals by proposing a narrative literature review. Then determine the review questions, namely what factors influence service innovation in the hospital. Then compile inclusion criteria that depend on the review questions asked. Inclusion criteria include population, concept and context. The inclusion criteria in this literature review are 1) Population: hospital. 2) Concept: hospital innovation, service innovation. 3) Context: factors that influence service innovation in hospitals. 4) Literature entered; with quantitative, qualitative, and review designs, published for the last 5 years starting January 1, 2015, in English. 5) Literature will be excluded if the concepts discussed are not published in a peer-reviewed journal. This study uses a search strategy that aims to find literature that has the potential to be selected according to the objectives of the review. Search The search strategy in the literature review is divided into 3 stages.

Initial searches were made of at least two online databases relevant to the topic via Google Scholar, Science Direct, PubMed, ProQuest. The search was carried out on this source and took published data starting from January 1, 2015. 


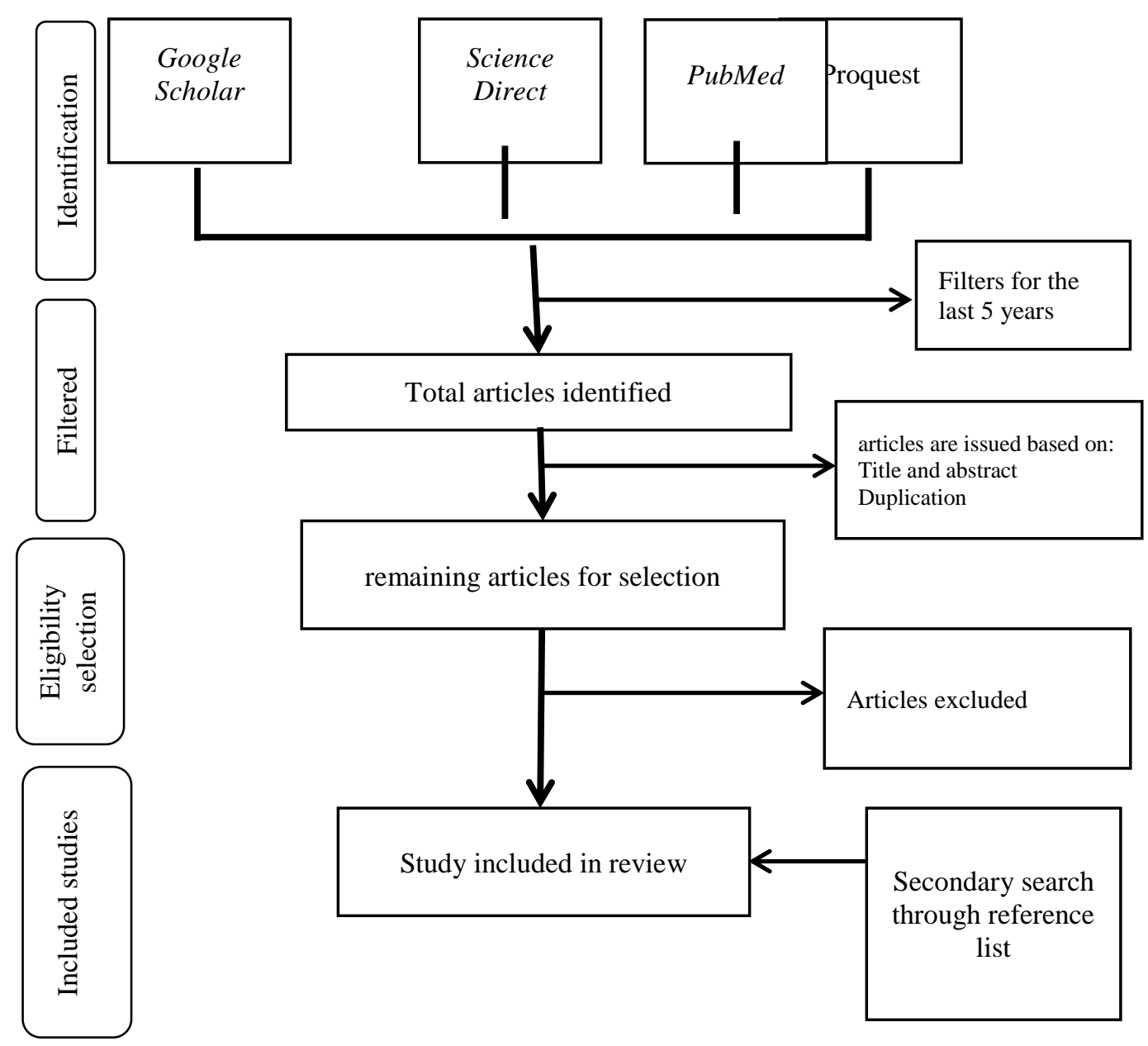

Figure 1. Initial search algorithm

Using identified keywords which are searched on online databases. The keywords used are; 1) Population: Hospital. 2) Concept: Hospital innovation, service innovation. 3) Context: Innovation factor OR factor influence OR Hospital OR

Tracing a list of references from identified literature that may be included as additional sources. In analyzing, the authors classified papers describing what factors influence service innovation in hospitals

\section{Results and Discussion}

Based on the selection results from several article sources based on keywords, Google Scholar totaled 17,400, Science Direct totaled 22,165, Pubmed totaled 10,943 and Proquest totaled 112,475 . Then from the initial total search, then filtered based on the year of publication starting from the last 5 years the total number of articles obtained was 6,514. then the article was reselected and issued based on the title and abstract and the duplication that was not suitable so that it became 60 articles. From the 60 articles, they were excluded based on the inclusion criteria into 27 articles. The steps in data extraction can be seen in Figure 2. 


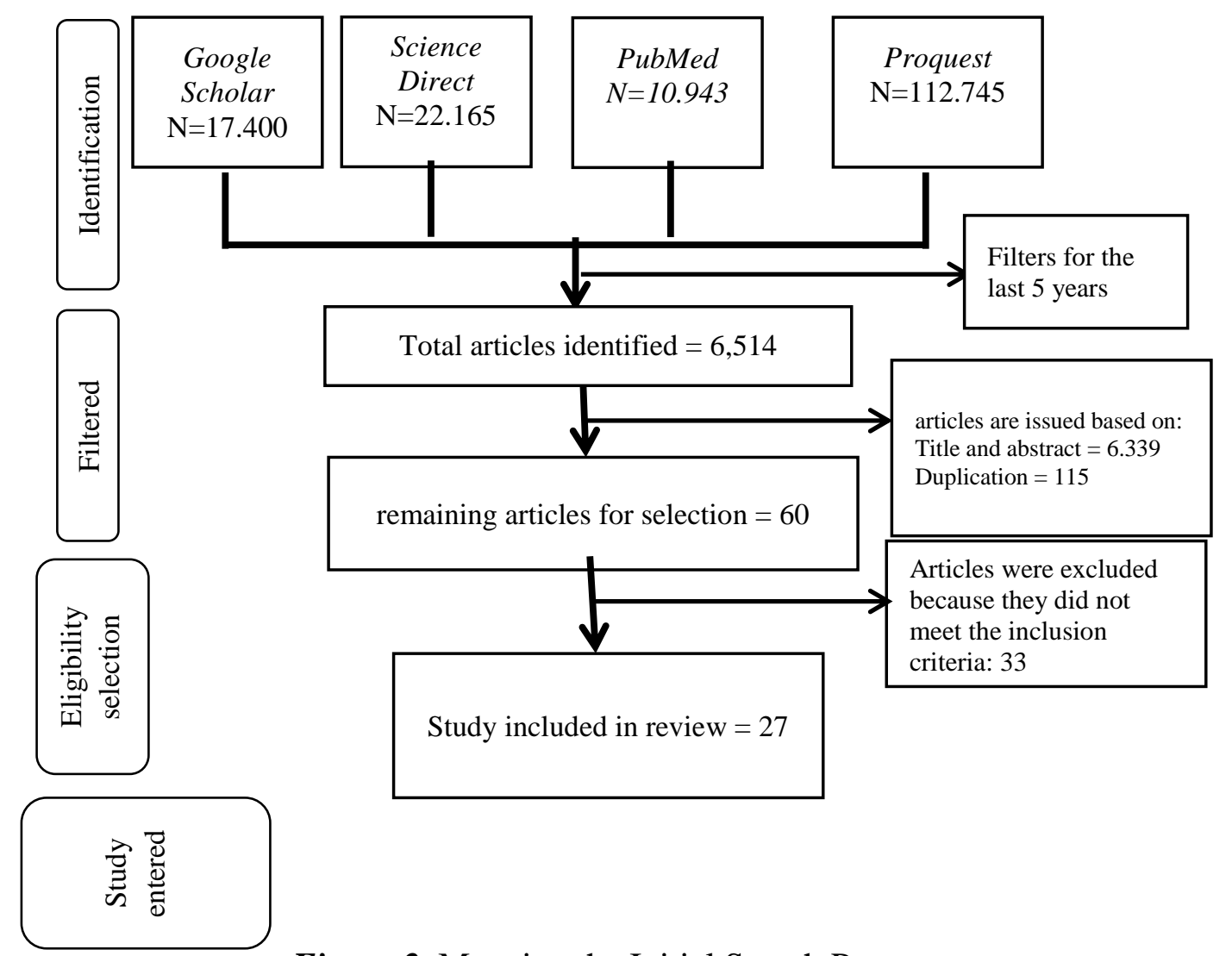

Figure 2. Mapping the Initial Search Process 
Table 1. Literature published and analyzed

\begin{tabular}{|c|c|c|c|c|c|c|}
\hline No & $\begin{array}{c}\text { Author's Name, Title, } \\
\text { Journal }\end{array}$ & $\begin{array}{l}\text { Year } \\
\text { of } \\
\text { Publi } \\
\text { catio } \\
\text { n }\end{array}$ & State & Purpose & Methods & Similarity \\
\hline 1 & $\begin{array}{l}\text { Maren Batalden et al, } \\
\text { Coproduction of } \\
\text { healthcare service. BMJ } \\
\text { Qual Saf 2016;25:509- } \\
517\end{array}$ & 2017 & USA & $\begin{array}{l}\text { To explore production principles } \\
\text { that have implications and } \\
\text { challenges for the development of } \\
\text { health professionals, for design } \\
\text { service delivery systems and for } \\
\text { understanding and measuring } \\
\text { benefits in healthcare }\end{array}$ & $\begin{array}{l}\text { Conseptual } \\
\text { Framework }\end{array}$ & $\begin{array}{l}\text { This research looks at } \\
\text { new productions and } \\
\text { new innovations in } \\
\text { health care and their } \\
\text { impact on health care }\end{array}$ \\
\hline 2. & $\begin{array}{l}\text { Durst, S., et al. } \\
\text { Service innovation and its } \\
\text { impact: What do we know } \\
\text { about? } \\
\text { Elsevier }\end{array}$ & 2015 & Europe & $\begin{array}{l}\text { To look at "service innovation" and } \\
\text { its impact on performance }\end{array}$ & $\begin{array}{l}\text { Systematic } \\
\text { Literature } \\
\text { Review }\end{array}$ & $\begin{array}{l}\text { This study shows that } \\
\text { there is knowledge of a } \\
\text { relationship between } \\
\text { service innovation and } \\
\text { performance, so that } \\
\text { performance becomes a } \\
\text { factor for service } \\
\text { innovation }\end{array}$ \\
\hline 3. & $\begin{array}{l}\text { Craig Kuziemsky, } \\
\text { Decision-making in } \\
\text { healthcare as a complex, } \\
\text { adaptive system, } \\
\text { Healthcare Management } \\
\text { Forum, Vol. 29(1) 4-7 }\end{array}$ & 2016 & Canada & $\begin{array}{l}\text { To review the challenges of using } \\
\text { traditional decision-making } \\
\text { approaches in health care and how } \\
\text { the insights from Complex } \\
\text { Adaptive Systems (CAS) can } \\
\text { support health care management. }\end{array}$ & $\begin{array}{l}\text { Conseptual } \\
\text { Framework }\end{array}$ & $\begin{array}{l}\text { Complex } \\
\text { System which is antive } \\
\text { innovation in health } \\
\text { services }\end{array}$ \\
\hline 4. & $\begin{array}{l}\text { Roberts JP,et al, } \\
\text { A design thinking } \\
\text { framework for healthcare } \\
\text { management and } \\
\text { innovation. Healthcare, } \\
\text { Elsevier }\end{array}$ & 2016 & US & $\begin{array}{l}\text { To see how design thinking applies } \\
\text { to health care challenges and how } \\
\text { systems can capitalize on this and } \\
\text { see evidence in the problem- } \\
\text { solving process in health care. }\end{array}$ & $\begin{array}{l}\text { Conseprual } \\
\text { Framework }\end{array}$ & $\begin{array}{l}\text { A design concept that is } \\
\text { an innovation in health } \\
\text { services }\end{array}$ \\
\hline
\end{tabular}




\begin{tabular}{|c|c|c|c|c|c|c|}
\hline 5. & $\begin{array}{l}\text { Seyed Samad Hossein. Et } \\
\text { al. The Impact of } \\
\text { Knowledge Management } \\
\text { Strategy on Service } \\
\text { Innovation Performance } \\
\text { in Private and Public } \\
\text { Hospitals, Iranian } \\
\text { Journal of Management } \\
\text { Studies (IJMS) Vol. 12, } \\
\text { No. 1, Winter } 2019 \text { Print } \\
\text { ISSN: 2008-7055 pp. 1-24 }\end{array}$ & 2019 & Iran & $\begin{array}{l}\text { To investigate the comparative } \\
\text { effect of knowledge management } \\
\text { strategies on service innovation } \\
\text { performance in public and private } \\
\text { hospitals through the mediating } \\
\text { role of knowledge management } \\
\text { practices. }\end{array}$ & $\begin{array}{l}\text { Literature } \\
\text { Review }\end{array}$ & $\begin{array}{l}\text { Knowledge Management } \\
\text { Strategy affects service } \\
\text { innovation in hospitals. }\end{array}$ \\
\hline 6. & $\begin{array}{l}\text { Hamideh Ravand et al, } \\
\text { Relationship between } \\
\text { Transformational } \\
\text { Leadership and Process } \\
\text { and Service Innovation in } \\
\text { a Teaching Hospital of } \\
\text { Tehran University of } \\
\text { Medical Sciences, } \\
\text { Iranian Journal of } \\
\text { Nursing Research (IJNR), } \\
\text { July-August 2017, Volume } \\
\text { 12, Issue } 3\end{array}$ & 2017 & Iran & $\begin{array}{l}\text { To investigate the relationship } \\
\text { between transformational } \\
\text { leadership and process and service } \\
\text { innovation in teaching hospitals }\end{array}$ & Survey & $\begin{array}{l}\text { Transformational } \\
\text { leadership is one of the } \\
\text { factors in service } \\
\text { innovation in hospitals }\end{array}$ \\
\hline 7 & $\begin{array}{l}\text { Laudio Guarcello, } \\
\text { Service Innovation in } \\
\text { Healthcare: A Systematic } \\
\text { Literature Review, } \\
\text { Latin American Business } \\
\text { Review }\end{array}$ & 2020 & USA & $\begin{array}{l}\text { To summarize and analyze } \\
\text { evidence on how innovative } \\
\text { services are in health care }\end{array}$ & $\begin{array}{l}\text { Systematic } \\
\text { Review }\end{array}$ & $\begin{array}{l}\text { Summarize and analyze } \\
\text { the literature on service } \\
\text { innovation factors in } \\
\text { health care }\end{array}$ \\
\hline 8. & $\begin{array}{l}\text { Leonard L. Berry et al } \\
\text { Service innovation is } \\
\text { urgent in healthcare }\end{array}$ & 2019 & USA & $\begin{array}{l}\text { To explain the importance of } \\
\text { service innovation in health care }\end{array}$ & $\begin{array}{l}\text { Conseptual } \\
\text { Framework }\end{array}$ & $\begin{array}{l}\text { Service innovation is } \\
\text { important by looking at } \\
\text { the factors that determine }\end{array}$ \\
\hline
\end{tabular}




\begin{tabular}{|c|c|c|c|c|c|c|}
\hline & $\begin{array}{l}\text { AMS Review (2019) } \\
\text { 9:78-92 }\end{array}$ & & & & & $\begin{array}{l}\text { the importance of service } \\
\text { innovation }\end{array}$ \\
\hline 9 & $\begin{array}{l}\text { Amanda Fox, et al } \\
\text { A theoretical framework } \\
\text { to support research of } \\
\text { health } \\
\text { service innovation } \\
\text { Australian Health Review, } \\
2015,39,70-75\end{array}$ & 2015 & $\begin{array}{c}\text { Australi } \\
\mathrm{a}\end{array}$ & $\begin{array}{l}\text { To provide a thorough examination } \\
\text { of research findings and provide a } \\
\text { suitable theoretical framework for } \\
\text { testing the sustainability of } \\
\text { healthcare innovation. }\end{array}$ & $\begin{array}{l}\text { Integrative } \\
\text { Literature } \\
\text { Review }\end{array}$ & $\begin{array}{l}\text { Theory of service } \\
\text { innovation in the world } \\
\text { of health }\end{array}$ \\
\hline 10. & $\begin{array}{l}\text { Vatcharapong Sukkird et } \\
\text { al, } \\
\text { Technology challenges to } \\
\text { healthcare service } \\
\text { innovation in aging Asia: } \\
\text { Case of value co-creation } \\
\text { in emergency medical } \\
\text { support system, } \\
\text { Elsevier Technology in } \\
\text { Society xxx (2015) 1e7 }\end{array}$ & 2015 & $\begin{array}{c}\text { Thailan } \\
\mathrm{d}\end{array}$ & $\begin{array}{l}\text { To identify the technological } \\
\text { challenges facing health care in } \\
\text { terms of a medical service system } \\
\text { created to support the demands of } \\
\text { elderly patients. }\end{array}$ & $\begin{array}{l}\text { Systematic } \\
\text { Literature } \\
\text { review }\end{array}$ & $\begin{array}{l}\text { Technological challenges } \\
\text { are service innovations } \\
\text { in the medical world or } \\
\text { in hospitals }\end{array}$ \\
\hline 11. & $\begin{array}{l}\text { Peter Samuelsson,, et al, } \\
\text { Incremental and Radical } \\
\text { Service Innovation } \\
\text { in Healthcare, Handbook } \\
\text { of Service Science, } \\
\text { Volume II, Service } \\
\text { Science: } \\
\text { Research and Innovations } \\
\text { in the Service Economy, }\end{array}$ & 2018 & Swedia & $\begin{array}{l}\text { To conceptualize incremental and } \\
\text { radical service innovations based } \\
\text { on internal and external changes } \\
\text { and identify four types of service } \\
\text { innovation and explore the effects } \\
\text { and processes of service innovation } \\
\text { diffusion. }\end{array}$ & $\begin{array}{l}\text { Literature } \\
\text { review }\end{array}$ & $\begin{array}{l}\text { Service innovation in the } \\
\text { hospital department }\end{array}$ \\
\hline 12. & $\begin{array}{l}\text { Maria R. A. Moreira, } \\
\text { Does innovation influence } \\
\text { the performance of } \\
\text { healthcare organizations? } \\
\text { Innovation }\end{array}$ & 2017 & Portugis & $\begin{array}{l}\text { To analyze whether some types of } \\
\text { innovation affect relevant } \\
\text { performance measures in health } \\
\text { institutions }\end{array}$ & $\begin{array}{l}\text { Conceptual } \\
\text { Framework }\end{array}$ & $\begin{array}{l}\text { The performance of } \\
\text { employees in health } \\
\text { institutions or hospitals } \\
\text { has an effect on service } \\
\text { innovation in hospitals }\end{array}$ \\
\hline
\end{tabular}




\begin{tabular}{|c|c|c|c|c|c|c|}
\hline & $\begin{array}{l}\text { Organization \& } \\
\text { Management } \\
\text { ISSN: } 1447-9338 \text { (Print) } \\
2204-0226\end{array}$ & & & & & \\
\hline 13. & $\begin{array}{l}\text { Anne Cleven et al, } \\
\text { Healthcare quality } \\
\text { innovation and } \\
\text { performance through } \\
\text { process orientation: } \\
\text { Evidence } \\
\text { from general hospitals in } \\
\text { Switzerland } \\
\text { Elsevier, Technological } \\
\text { Forecasting \& Social } \\
\text { Change }\end{array}$ & 2016 & $\begin{array}{l}\text { Switzerl } \\
\text { and }\end{array}$ & $\begin{array}{l}\text { To describe the quality of the } \\
\text { health service innovation, its } \\
\text { performance and process } \\
\text { orientation }\end{array}$ & $\begin{array}{l}\text { Conseptual } \\
\text { Framework }\end{array}$ & $\begin{array}{l}\text { Seeing the relationship } \\
\text { between service } \\
\text { innovations } \\
\text { performance and the } \\
\text { process of acceptance in } \\
\text { health services }\end{array}$ \\
\hline 14 & $\begin{array}{l}\text { Ko, Yu Kyung1 et al } \\
\text { Organizational Culture } \\
\text { and Organizational } \\
\text { Support as Factors } \\
\text { Affecting } \\
\text { the Innovative Behaviors } \\
\text { of General Hospital } \\
\text { Nurses } \\
\text { Korean Acad Nurs } \\
\text { Adm( 간호행정학회지) } \\
\text { Vol. } 21 \text { No. 2, 223-231, } \\
\text { March } 2015\end{array}$ & 2015 & Korea & $\begin{array}{l}\text { To identify the effects of } \\
\text { organizational culture, and } \\
\text { organizational support an } \\
\text { innovation in hospitals }\end{array}$ & Survey & $\begin{array}{l}\text { The relationship between } \\
\text { organizational culture } \\
\text { and organizational } \\
\text { support is one of the } \\
\text { driving factors for } \\
\text { service innovation in } \\
\text { hospitals }\end{array}$ \\
\hline 15. & $\begin{array}{l}\text { Yu Mu,et al } \\
\text { Employee involvement in } \\
\text { ideation and healthcare } \\
\text { service innovation quality } \\
\text { The Service Industries } \\
\text { Journal }\end{array}$ & 2017 & Jerman & $\begin{array}{l}\text { To examine the influence of } \\
\text { employee and top management } \\
\text { involvement in the ideation process } \\
\text { on the quality of health service } \\
\text { innovation }\end{array}$ & $\begin{array}{l}\text { Literature } \\
\text { Review }\end{array}$ & $\begin{array}{l}\text { Involvement between } \\
\text { employees and top } \\
\text { management is a factor } \\
\text { in influencing service } \\
\text { innovation in the hospital }\end{array}$ \\
\hline
\end{tabular}




\begin{tabular}{|c|c|c|c|c|c|c|}
\hline 16. & $\begin{array}{l}\text { Ole Hanseth1et al } \\
\text { Flexible generification: } \\
\text { ICT standardization } \\
\text { strategies and service } \\
\text { innovation in health care } \\
\text { European Journal of } \\
\text { Information Systems } \\
\text { (2015) } 24,645-663\end{array}$ & 2015 & $\begin{array}{c}\text { Norwegi } \\
\mathrm{a}\end{array}$ & $\begin{array}{l}\text { Identify links between standardized } \\
\text { strategies and service innovation in } \\
\text { the health sector }\end{array}$ & Case Study & $\begin{array}{l}\text { The standardized } \\
\text { strategy is a factor } \\
\text { influencing service } \\
\text { innovation in hospitals }\end{array}$ \\
\hline 17 & $\begin{array}{l}\text { Anton Klarin, } \\
\text { Mapping product and } \\
\text { service innovation: A } \\
\text { bibliometric analysis and } \\
\text { a } \\
\text { Typology, } \\
\text { Elsevier Technological } \\
\text { Forecasting \& Social } \\
\text { Change } 149 \text { (2019) } \\
119776\end{array}$ & 2019 & $\begin{array}{c}\text { Australi } \\
\mathrm{a}\end{array}$ & $\begin{array}{l}\text { To see and review some literature } \\
\text { about how product innovation and } \\
\text { service innovation }\end{array}$ & $\begin{array}{l}\text { Systematic } \\
\text { literature } \\
\text { Review }\end{array}$ & $\begin{array}{lr}\text { Discusses } & \text { service } \\
\text { innovation in general and } \\
\text { reviews some reliable } \\
\text { literature }\end{array}$ \\
\hline 18 & $\begin{array}{l}\text { Ian Vickers, } \\
\text { Public service innovation } \\
\text { and multiple institutional } \\
\text { logics: The case of } \\
\text { hybrid social enterprise } \\
\text { providers of health and } \\
\text { wellbeing, } \\
\text { Elsevier Research Policy }\end{array}$ & 2017 & London & $\begin{array}{l}\text { To see how service innovations are } \\
\text { in the public sector and their } \\
\text { relationship with health service } \\
\text { providers }\end{array}$ & Case Study & $\begin{array}{l}\text { Service innovations in } \\
\text { the world of health have } \\
\text { many implications for } \\
\text { health care providers } \\
\text { such as hospitals }\end{array}$ \\
\hline 19 & $\begin{array}{l}\text { Thune \& Mina, } \\
\text { Hospitals as innovators in } \\
\text { the health-care system: A } \\
\text { literature review and } \\
\text { research agenda, } \\
\text { Elsevier, Research Policy }\end{array}$ & 2016 & $\begin{array}{c}\text { Norwegi } \\
\mathrm{a}\end{array}$ & $\begin{array}{l}\text { To increase understanding of the } \\
\text { role of the hospital in the } \\
\text { innovation generation }\end{array}$ & $\begin{array}{l}\text { Literature } \\
\text { Review }\end{array}$ & $\begin{array}{l}\text { The role of the hospital } \\
\text { is one of the factors in } \\
\text { developing service } \\
\text { innovations in the } \\
\text { hospital itself }\end{array}$ \\
\hline 20 & Jenny Karslon et al & 2016 & Norwegi & To study the contribution of & Case Study & The \\
\hline
\end{tabular}




\begin{tabular}{|c|c|c|c|c|c|c|}
\hline & $\begin{array}{l}\text { Exploring front-line } \\
\text { employee } \\
\text { contributions to service } \\
\text { innovation } \\
\text { European Journal of } \\
\text { Marketing }\end{array}$ & & $\mathrm{a}$ & $\begin{array}{l}\text { employees on this front in service } \\
\text { innovation, when and how they } \\
\text { contribute to be involved in it }\end{array}$ & & $\begin{array}{l}\text { involvement of } \\
\text { employees is one of the } \\
\text { influencing factors in } \\
\text { service innovation in the } \\
\text { hospital }\end{array}$ \\
\hline 21 & $\begin{array}{l}\text { Christoph Rasche, et al } \\
\text { Service Model Innovation } \\
\text { in Hospitals: } \\
\text { Beyond Expert } \\
\text { Organizations }\end{array}$ & 2016 & Jerman & $\begin{array}{l}\text { To find out why the organization } \\
\text { should define services from a } \\
\text { patient perspective and why the } \\
\text { organization should focus on } \\
\text { patient and patient safety issues }\end{array}$ & $\begin{array}{l}\text { Conseptua } \\
\text { Framework }\end{array}$ & $\begin{array}{l}\text { Looking at the model of } \\
\text { service innovation in } \\
\text { hospitals and the } \\
\text { influence of the } \\
\text { hospital's role on patient } \\
\text { safety }\end{array}$ \\
\hline 22 & $\begin{array}{l}\text { Qiang Wang, et al } \\
\text { Modes of service } \\
\text { innovation: } \\
\text { a typology } \\
\text { IMDS }\end{array}$ & 2015 & China & $\begin{array}{l}\text { To explore the differences between } \\
\text { the forms of service innovation by } \\
\text { examining the business innovation } \\
\text { model with two models, namely } \\
\text { process innovation and service } \\
\text { innovation }\end{array}$ & $\begin{array}{l}\text { Literature } \\
\text { Revuew }\end{array}$ & $\begin{array}{l}\text { See how service } \\
\text { innovation and its impact } \\
\text { and impact on the health } \\
\text { sector }\end{array}$ \\
\hline 23 & $\begin{array}{l}\text { Dr. Mohammed Sultan } \\
\text { Majied Mahasneh, et al } \\
\text { Innovation in Health } \\
\text { Services alignment with } \\
\text { the Competitive } \\
\text { Advantage Achievement in } \\
\text { Private Hospitals in Saudi } \\
\text { Arabia: Strategic } \\
\text { Evidence, } \\
\text { International Journal of } \\
\text { Business and Social } \\
\text { Science Vol. } 11 \cdot \text { No. } 3 \cdot \\
\text { March } 2020\end{array}$ & 2020 & $\begin{array}{l}\text { Saudi } \\
\text { Arabiah }\end{array}$ & $\begin{array}{l}\text { To examine the level of innovation } \\
\text { dimensions in health care (products } \\
\text { and processes) that correspond to } \\
\text { the competitive advantage of health } \\
\text { care }\end{array}$ & $\begin{array}{l}\text { Literature } \\
\text { Review }\end{array}$ & $\begin{array}{l}\text { The existence of a level } \\
\text { in service innovation is a } \\
\text { factor in the innovation } \\
\text { itself in the world of } \\
\text { health }\end{array}$ \\
\hline 24 & $\begin{array}{l}\text { Jamie Newman et al, } \\
\text { Inpatient Beds for }\end{array}$ & 2019 & $\overline{U S}$ & $\begin{array}{l}\text { To see and conduct a survey of } \\
\text { hospital innovations in the form of }\end{array}$ & Survey & $\begin{array}{l}\text { The procurement of } \\
\text { fabrication for inpatient }\end{array}$ \\
\hline
\end{tabular}




\begin{tabular}{|c|c|c|c|c|c|c|}
\hline & $\begin{array}{l}\text { Patients With } \\
\text { Syphilisd Hospital } \\
\text { Innovation 1919,JAMA }\end{array}$ & & & $\begin{array}{l}\text { providing inpatient beds for } \\
\text { patients }\end{array}$ & & $\begin{array}{l}\text { beds is an innovation in } \\
\text { home services }\end{array}$ \\
\hline 25 & $\begin{array}{l}\text { Seong No Yoon, et al } \\
\text { Effects of innovation } \\
\text { leadership and supply } \\
\text { chain innovation on } \\
\text { supply chain } \\
\text { efficiency: Focusing on } \\
\text { hospital size, } \\
\text { Elsevier Technological } \\
\text { Forecasting \& Social } \\
\text { Change xxx }\end{array}$ & 2016 & Korea & $\begin{array}{l}\text { To examine the effects of } \\
\text { innovation leadership and Supply } \\
\text { Chain (SC) innovation on SC } \\
\text { efficiency in healthcare } \\
\text { organizations }\end{array}$ & $\begin{array}{l}\text { Literature } \\
\text { Review }\end{array}$ & $\begin{array}{l}\text { The existence of an } \\
\text { innovation leadership } \\
\text { style is one of the factors } \\
\text { that influence service } \\
\text { innovation in hospitals }\end{array}$ \\
\hline 26 & $\begin{array}{l}\text { Mi-sook Yeum et al, } \\
\text { The Effect of Internal } \\
\text { Marketing on Competitive } \\
\text { Advantage as } \\
\text { Organizational Coaching } \\
\text { - Mediating Effect of } \\
\text { Service Innovation } \\
\text { International Journal of } \\
\text { Business Policy and } \\
\text { Strategy Management } \\
\text { Vol.6, No.1 (2019), pp.7- } \\
\text { 12 }\end{array}$ & 2019 & Korea & $\begin{array}{l}\text { To examine the effect of internal } \\
\text { marketing or internal marketing on } \\
\text { competitive advantage by means of } \\
\text { funding the organization to obtain } \\
\text { that competitive advantage. }\end{array}$ & $\begin{array}{l}\text { Literature } \\
\text { Review }\end{array}$ & $\begin{array}{l}\text { Internal marketing is one } \\
\text { of the factors that } \\
\text { influence } \\
\text { achievement of service } \\
\text { innovation in hospitals. }\end{array}$ \\
\hline 27 & $\begin{array}{l}\text { Md Anwarul Islam, et al } \\
\text { Effect of knowledge } \\
\text { management on } \\
\text { service innovation in } \\
\text { academic libraries }\end{array}$ & 2017 & USA & $\begin{array}{l}\text { To investigate the effect of } \\
\text { knowledge management on service } \\
\text { innovation in academic libraries }\end{array}$ & $\begin{array}{l}\text { Literature } \\
\text { Review }\end{array}$ & $\begin{array}{l}\text { Knowledge management } \\
\text { also influences service } \\
\text { innovation in the health } \\
\text { sector in hospitals }\end{array}$ \\
\hline
\end{tabular}

Source: Primary Data, 2020 


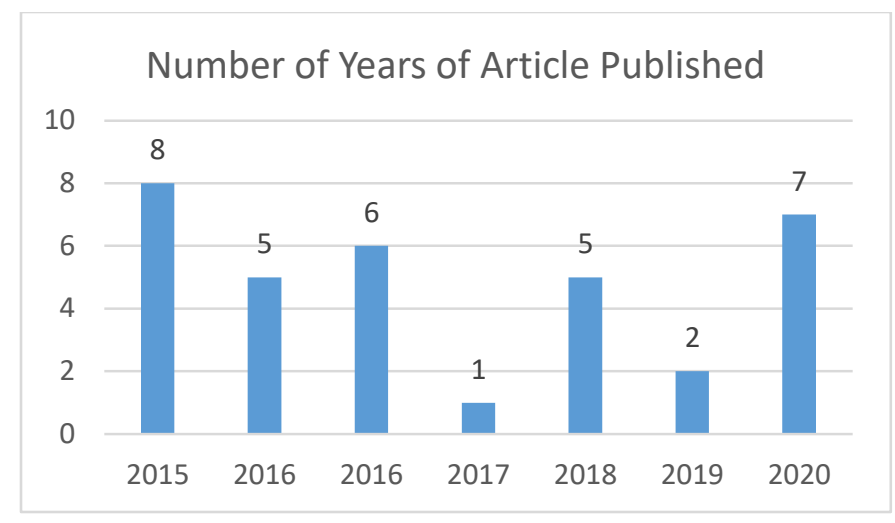

Figure 3. Number of Years of Published Articles

Overall, the total number of articles analyzed were 27 articles that met the inclusion and exclusion criteria can be seen in table 1. Based on the results of the analysis of the papers, the number of literature analyzes fluctuated in terms of the year of publication. Whereas in Figure 3, it can be seen that most of the published articles come from two countries, namely the UK and the US.

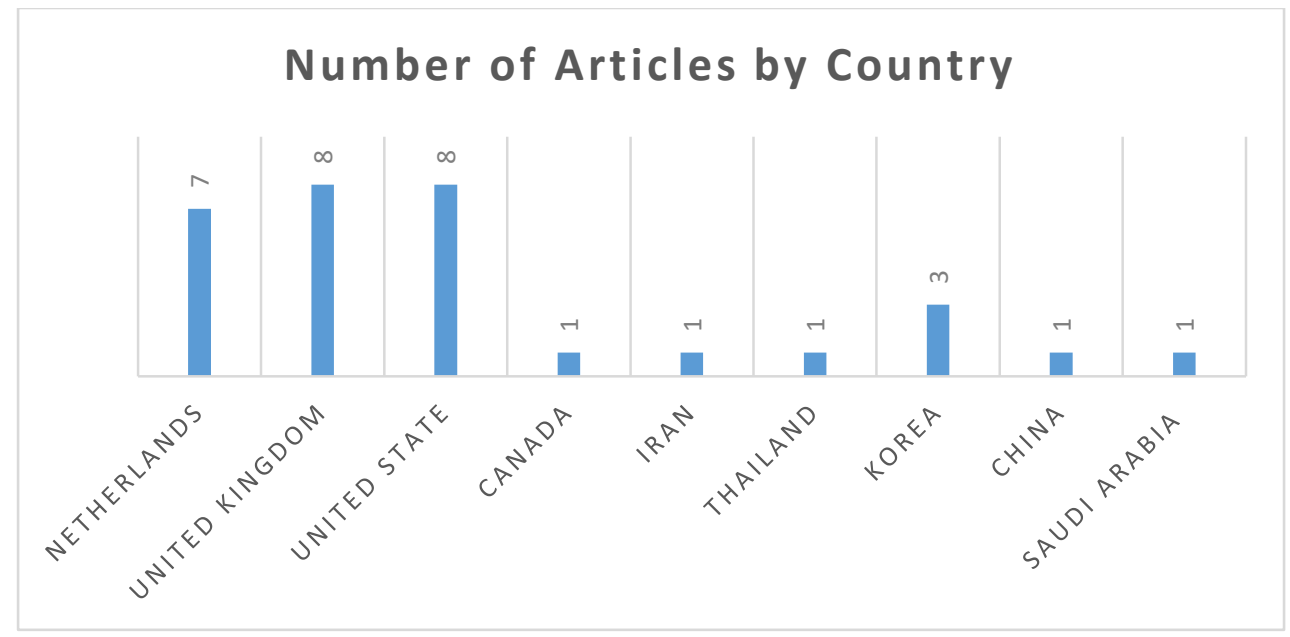

Figure 4. Number of Articles by Country

To better understand the rarity of this paper, the authors classify the papers based on the type of research can be seen in figure 4 .

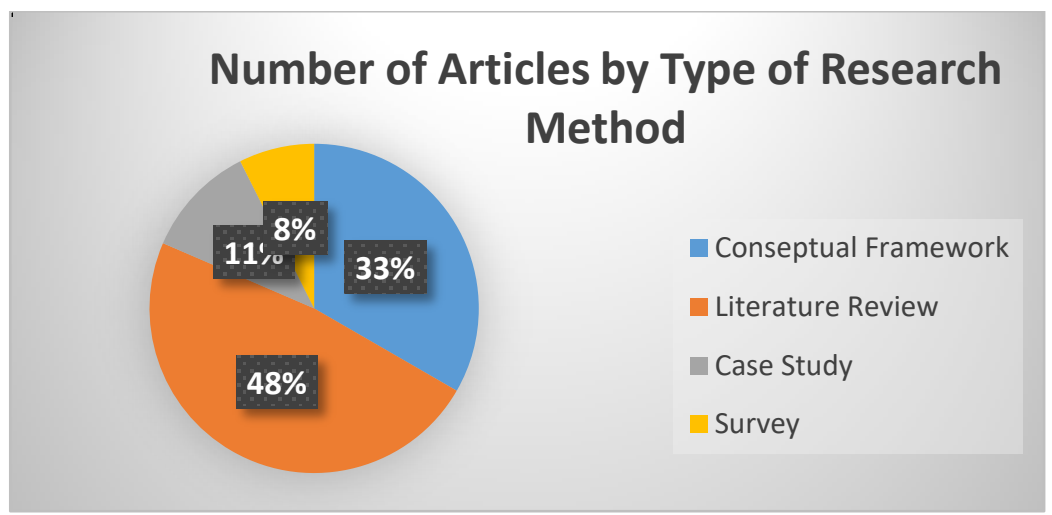

Figure 5. Number of Articles by Type of Research 
In diagram 3, it illustrates the number of articles based on the type of research, where most of the article research methods analyzed used the literature review method, which was $48 \%$. Then the conceptual framework literary method was 33\%, the Case Study method was $11 \%$ and the Survey method was $8 \%$.

\section{Influence Factors of Service Innovation in Hospitals}

\section{Literature Review}

In this section, the authors present the findings of analysis of several literature based on the topics raised, namely the factors that influence service innovation in hospitals. With the rapidly changing competitive environment, organizations including hospitals have concerns about how to increase their competitive advantage. One solution to this problem is internal marketing (IM) which affects employee attitudes and changes the service process with new ideas, which in turn leads to competitive advantage. This is in line with Yeum's (2019) research, which uses three elements of internal marketing: communication, empowerment, and appreciation. IM has a positive effect on service innovation. To get a competitive advantage in an organization comes from how to manage and build communication, education \& training, appreciation, empowerment.

Whereas in Hosseini's (2019) paper which aims to study the influence of knowledge management strategies on practice to achieve better service innovation performance in the health sector. In recent theoretical developments, knowledge management activities have a key role in improving innovation performance (Moosavi Jad et al (2017) in Yeum, 2019). Therefore, the achievement of innovation is highly dependent on the knowledge, skills and commitment of employees as key factors in the value creation process. Knowledge management strategies result in more efficient use of human resources, detection of deficiencies in organizational knowledge, more effective and efficient employee learning, provision of goods and services with more added value, customer and employee content, prevention of error repetition, duplication and time economy. ${ }^{7}$.

In general, Hosseini's research shows that this knowledge management practice is linked to innovative excellence. The reason is that the combination of existing and newly acquired knowledge can play an indisputable and extraordinary role in service innovation. In addition, organizations to implement effective knowledge management practices must implement appropriate strategies. They also have to share knowledge with employees. With the management of intellectual resources and new ideas presented by employees, the hospital is able to provide innovative ideas, tools and services, and processes for their therapy section. Overall, there is sufficient support for knowledge management practices based on knowledge management strategies in relation to developing innovations in new services in order to provide better services to patients in hospital services. In addition, according to Roberts (2016), with a design mindset in health service management, a renewal in the world of health also has a big effect.

One of the reasons behind an underdeveloped understanding of service innovation may still be assigned to the predominance of industrial and technological approaches to innovation. If the organization wants to adopt a service-based strategy, it is important to be able to measure the value of this type of innovation, that is, its impact on company performance. thus, disrupting the optimal allocation of their fear resources. 
Innovation has been widely recognized as the key to organizational success and leadership style is one of the most important dynamic factors in organizational progress or stagnation. Transformational leadership by creating change in the organization can stimulate staff innovation. The results showed a positive and significant relationship between transformational leadership and process and service innovation. In addition, there is a positive and significant relationship between all components of transformational leadership (idealized influence, intellectual stimulation, individual judgment and inspirational motivation) and process and service innovation. The success of service organizations is directly related to employees and how they behave. By creating commitment and responsibility to employees, it causes the organization to grow and survive. The role of transformational leadership encourages employees to think creatively and innovatively.

The increasing demand for health services demands innovation. According to Fox (2015), there are several factors that influence the sustainability of an innovation in the world of health.

\section{Political factors}

Politics that focus on one particular policy will greatly affect the sustainability of an innovation and political sustainability is considered to increase when management leaders and organizational culture support innovation. Therefore, the role of the leadership element and the involvement of staff are the main focus of the political segment.

\section{Organizational factors}

Flexibility and adaptation of innovation to suit the context and organization have been recognized as proponents of sustainability innovation. Operational governance agreed upon in an organization and effective communication within an organization will increase the sustainability of innovation. Lack of meetings and teamwork leads to a lack of support for innovation and poor sustainability.

\section{Financial Factors}

Innovations that have a dedicated, sustainable budget and are sufficient to meet a need are more likely to be used by an organization. The financial factors of this theoretical framework ensure funding sources, planning strategies and evaluation of innovations.

\section{Labor factor}

The workforce or staff and their roles will change according to the minimum amount of training attended. Using high quality training resources will also support the sustainability of an innovation. Lack of continuity or not having adequate staff to implement innovations is a threat to sustainability.

\section{Innovation-specific factors}

The nature and type of innovation will play a role in the sustainability of the innovation itself. An important feature of an innovation is fluidity and adaptability to respond to changing funding and service requirements based on local decision making and needs. Consequently, innovationspecific factors focus on identifying supports and barriers to innovation strategies and evaluating self-innovation.

These factors are a dynamic collection of characteristics and may be related to one another. As a direct consequence, innovation services are emerging as a research priority to better understand 
how health care providers can improve health care and promote services by combining and recombining innovative and renewable resources. According to Berry, 2019, one of the factors that influence the success of a service innovation in the hospital is the presence of a strong expertise in marketing a service. Health care needs to learn how to improve marketability so that services can be utilized and utilized optimally.

In the literature Thune (2016) devotes special attention to the role of medical doctors and looks in detail at the role of physicians as inventors, their role in developing new products, and the ways in which these activities are carried out in collaboration with industry. The literature on hospitals as innovative organizations is, as one might expect, primarily internally oriented to hospitals. Some of this literature also has a special focus on use and dissemination, particularly on questions about complementary service innovations, adaptations, and post-implementation improvements. This literature has a learning perspective in organizations and tends to emphasize organizational features and management practices that promote openness and participation in innovation activities among hospital employees.

\section{Conclusion}

From some of the literature analyzed, 27 journals were in accordance with the topics and objectives of the study, namely analyzing and examining the factors that influence service innovation in hospitals. Most of the literature analyzed uses the literature review method or literature review. As for the results obtained from the analysis of several literature, there are several activities that the hospital can do such as having a good communication system with members in the hospital organization, especially between leaders and members, empowering members and providing an appropriate and fair reward system so that the organization is strived for. experience change by accepting service innovations. In addition, the existence of the hospital's internal marketing policy increases employee satisfaction and loyalty. If employees are satisfied, it will influence a hospital to increase innovation in its services. There is also a need for a transformational leadership style for hospital leaders. If management in the hospital adopts a transformational leadership style, the organization's ability to increase to create innovation and make the organization experience growth and progress.

\section{References}

Berry, L. L. (2019). Service innovation is urgent in healthcare. AMS Review, 9(1-2), 78-92.

Cleven, A., Mettler, T., Rohner, P., \& Winter, R. (2016). Healthcare quality innovation and performance through process orientation: Evidence from general hospitals in Switzerland. Technological Forecasting and Social Change, 113, 386-395.

Fox, A., Gardner, G., \& Osborne, S. (2015). A theoretical framework to support research of health service innovation. Australian Health Review, 39(1), 70-75.

Guarcello, C., \& de Vargas, E. R. (2020). Service Innovation in Healthcare: A Systematic Literature Review. Latin American Business Review, 1-17.

Hanseth, O., \& Bygstad, B. (2015). Flexible generification: ICT standardization strategies and service innovation in health care. European Journal of Information Systems, 24(6), 645663.

Islam, M. A., Agarwal, N. K., \& Ikeda, M. (2017). Effect of knowledge management on service innovation in academic libraries. IFLA journal, 43(3), 266-281.

Copyright $\left({ }^{\circ}\right.$ 2020, Journal of Asian Multicultural Research for Medical and Health Science Study, Under the license CC BY-SA 4.0 
Karlsson, J., \& Skålén, P. (2015). Exploring front-line employee contributions to service innovation. European Journal of Marketing.

Klarin, A. (2019). Mapping product and service innovation: A bibliometric analysis and a typology. Technological Forecasting and Social Change, 149, 119776.

Ko, Y. K., Yu, S., \& Kang, K. H. (2015). Organizational culture and organizational support as factors affecting the innovative behaviors of general hospital nurses. Journal of Korean Academy of Nursing Administration, 21(2), 223-231.

Mahasneh, M. M., Alnahdi, S. A., \& Bani Hani, J. S. (2020). Innovation in health services alignment with the competitive advantage achievement in private hospitals in Saudi Arabia: Strategic evidence. International Journal of Business and Social Science, 11(3), 58-68.

Moreira, M. R., Gherman, M., \& Sousa, P. S. (2017). Does innovation influence the performance of healthcare organizations?. Innovation, 19(3), 335-352.

Mu, Y., Bossink, B., \& Vinig, T. (2018). Employee involvement in ideation and healthcare service innovation quality. The Service Industries Journal, 38(1-2), 67-86.

Newman, J., \& Ziemer, R. (2019). Inpatient Beds for Patients With Syphilis-Hospital Innovation 1919. Mayo Clinic Proceedings: Innovations, Quality \& Outcomes, 3(4), 483-484.

Rasche, C., Margaria, T., \& Floyd, B. D. (2017). Service model innovation in hospitals: Beyond expert organizations. In Service business model innovation in healthcare and hospital management (pp. 1-20). Springer, Cham.

Ravand, H., Darvish, H., \& Nasrabadi, A. N. (2017). Relationship between Transformational Leadership and Process and Service Innovation in a Teaching Hospital of Tehran University of Medical Sciences. Iranian Journal of Nursing Research, 12(3), 58-66.

Samuelsson, P., Witell, L., Gottfridsson, P., \& Elg, M. (2019). Incremental and radical service innovation in Healthcare. In Handbook of Service Science, Volume II (pp. 619-638). Springer, Cham.

Thune, T., \& Mina, A. (2016). Hospitals as innovators in the health-care system: A literature review and research agenda. Research Policy, 45(8), 1545-1557.

Vatcharapong, S., \& Shirahada, K. (2014, July). Technology challenges to healthcare service innovation in aging Asia: Case study of emergency medical service system. In Proceedings of PICMET'14 Conference: Portland International Center for Management of Engineering and Technology; Infrastructure and Service Integration (pp. 2791-2798). IEEE.

Vickers, I., Lyon, F., Sepulveda, L., \& McMullin, C. (2017). Public service innovation and multiple institutional logics: The case of hybrid social enterprise providers of health and wellbeing. Research Policy, 46(10), 1755-1768.

Wang, Q., Voss, C., Zhao, X., \& Wang, Z. (2015). Modes of service innovation: a typology. Industrial Management \& Data Systems. 
Yeum, M. S., Wee, K. H., \& Bang, W. S. (2020). The Effect of Internal Marketing on Competitive Advantage as Organizational Coaching-The Mediating Effect of Service Innovation. Journal of System and Management Sciences, 10(1), 62-71.

Yoon, S. N., Lee, D., \& Schniederjans, M. (2016). Effects of innovation leadership and supply chain innovation on supply chain efficiency: Focusing on hospital size. Technological Forecasting and Social Change, 113, 412-421. 